Trakya Eğitim Dergisi

Cilt 9, Sayı 1

Ocak 2019, 138-151

Geliş Tarihi: 11.10.2018

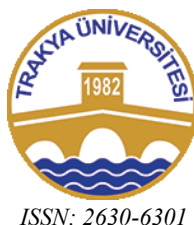

ISSN:2630-6301
Trakya Journal of Education

Volume 9, Issue 1

January 2019, 138-151

\title{
Fen Bilimleri Dersi Öğretim Programı Kazanımlarının Özel Amaçlar ve Alana Özgü Beceriler Bakımından İncelenmesi ${ }^{1}$
}

\author{
The Investigations of Science Curriculum Acquisitions in Terms of Special Purposes \\ and Field-Specific Skills
}

\author{
Hasan ÖZCAN², Hakkı İlker KOŞTUR ${ }^{3}$
}

\begin{abstract}
Öz: Bu araştırmanın amacı 2018 yılında güncellenen fen bilimleri dersi öğretim programında bulunan kazanımların, öğretim programında belirlenmiş olan özel amaçlar ve alana özgü beceriler açısından incelenmesidir. İncelemenin yapılabilmesi için öncelikle öğretim programındaki özel amaçlar ve alana özgü beceriler altında bulunan hedefler listelenmiş, bu hedeflere kısaca tema adı verilmiş, ardından kazanımlar incelenerek hangi kazanımın hangi temaya yönelik olduğu belirlenmiş ve bu bulgular yorumlanmıştır. Öğretim programında bulunan 302 kazanım belirlenen 13 temaya $339 \mathrm{kez}$ yerleşmiştir. Bulgular, kazanımların bilimsel süreç becerileri, bilgi ve yaşam becerileri ağırlıklı davranışlar içerdiğini göstermektedir. Diğer yandan, öğretim programının özel amaçları arasında bulunan sorumluluk, güvenlik bilinci, sosyobilimsel konular ve kariyer bilinci gibi birçok hedefin, kazanımlar arasında yeteri kadar yer bulamadığı tespit edilmiştir.
\end{abstract}

Anahtar sözcükler: Fen bilimleri dersi, ögretim programı, özel amaçlar, alana özgü beceriler

\section{Cite this article as:}

Özcan, H., \& Koştur, H., İ. (2019). Fen bilimleri dersi öğretim programı kazanımlarının özel amaçlar ve alana özgü beceriler bakımından incelenmesi. Trakya Eğitim Dergisi, 9(1), 138-151.

\section{EXTENDED ABSTRACT}

\section{Introduction}

Currently, there are 302 learning outcomes in the curriculum of the science curriculum: 36 in the third grade, 43 in the fourth grade, 36 in the fifth grade, 59 in the sixth grade, 67 in the seventh grade and 61 in the eighth grade. It can be interpreted that science-technology-engineering-mathematics (STEM) approach is adopted because the curriculum emphasizes such subjects as engineering, entrepreneurship, and innovative thinking skills. In order to develop the skills of engineering and entrepreneurship applications and to organize science festivals at the end of the year, starting from the fourth grade, in addition to lecture hours, 9 hours for 4th grades and 12 hours for 5th, 6th, 7th and 8th grades, total of 57 class hours were added to the curriculum.

Ten special aims have been determined in the science curriculum. These special aims will provide students with a basic knowledge of science subjects and engineering practices as well as individual, environmental and community relations; awareness of sustainable development; take responsibility; career awareness; entrepreneurial skills; the process of creation of scientific knowledge; to develop interest and curiosity towards nature and environment, to develop attitude; to be aware of the importance of safety in scientific studies and to create consciousness; to develop reasoning ability, scientific

\footnotetext{
${ }^{1} \mathrm{Bu}$ araştırmanın bir kısmı 27. Uluslararası Eğitim Bilimleri Kongresi'nde sözlü bildiri olarak sunulmuştur.

${ }^{2}$ Dr. Öğr.Üyesi, Aksaray Üniversitesi, hozcan@aksaray.edu.tr

${ }^{3}$ Dr. Öğr.Üyesi, Başkent Üniversitesi, kostur@baskent.edu.tr
} 
thinking habits and decision making skills using sociological aspects; universal moral values include elements such as national and cultural values and the adoption of scientific ethical principles. The specific aims of the curriculum can be seen as a blend of learning domains known as "affective" and "science-technology-society-environment" in 2005 and 2013 science curriculums.

"Science process skills" and "daily life skills", which were examined under the "skills" learning domain in the 2013 curriculum, united with "engineering and designing skills" and these group of skills are named "field-specific skills" in 2018 curriculum. In science process skills there are observing, measuring, classifying, recording data, hypothesizing, using data and constructing models, changing and controlling variables, and performing experiments; in daily life skills, there are analytical thinking, decision making, creative thinking, entrepreneurship, communication, teamwork skills, and engineering and designing skills. It is aimed to design a product with the skills of engineering and design with the knowledge and skills that the students gain.

\section{Purpose and Significance}

The purpose of this research is to examine learning acquisitions of the science curriculum which was updated in 2018, in terms of the special purposes and field-specific skills in the curriculum. In order to examine, firstly the special purposes and the field-specific skills in the curriculum were listed as themes and then, the learning acquisitions were examined and the theme they belong was determined.

This research is thought to be beneficial to the teachers of science, the applicants of the course and the curriculum developers related to the course as it identifies a relationship between the goals and the learning acquisitions of the curriculum and discusses this relationship with a comparison with the former curriculums.

\section{Method}

In this research, the science curriculum was examined by the content analysis technique from qualitative analysis methods. Content analysis is the categorization of verbal or written documents by scanning them for classification or summarization in terms of a problem or objective. In the analysis of the content made in the research, firstly 13 themes were identified including 10 special purposes and 3 field-specific skills by examining special purposes and specific skills in the curriculum, and then 302 learning acquisitions were examined and placed in the themes. The thematic placement of the learning acquisitions was carried out by two science educators who were the writers of this research and one curriculum development expert. Since 37 of the learning acquisitions have integrated behaviors or targets, they have been placed on more than one theme. Therefore, the data set of the research is created with 302 learning acquisitions that are settled 339 times to 13 themes. The analysis and interpretation of the data were conducted by using descriptive methods with the relations between determined themes, class levels and of relation to subject areas.

The themes created are: 1) Knowledge; 2) Producing solutions to problems; 3) Sustainable development awareness; 4) Taking responsibility; 5) Career awareness and entrepreneurial skills; 6) History and the nature of science; 7) Interest, curiosity, and attitudes; 8) Safety awareness; 9) Socioscientific issues; 10) Values and ethics; 11) Science process skills; 12) Daily life skills; 13) Engineering skills.

\section{Results}

The distribution of 302 learning acquisitions of the curriculum in the created themes, following results were obtained, respectively: Science process skills $(40,41 \%)$; Knowledge $(29,49 \%)$; Daily life skills (12,68\%); Engineering skills (3,2\%); Values and ethics (2,65\%); Producing solutions to problems $(2,35 \%)$; Sustainable development awareness $(2,06 \%)$; History and the nature of science $(2,06 \%)$; Interest, curiosity and attitudes $(1,77 \%)$; Safety awareness $(1,47 \%)$; Taking responsibility $(0,89 \%)$; Socioscientific issues $(\% 0,59)$; Career awareness and entrepreneurial skills $(0,29 \%)$.

\section{Discussion and Conclusion}

The results of the analysis of the data obtained from the study show that there are some problems in the harmony between the special aims and the field-specific skills in the science curriculum. For example, although career consciousness and entrepreneurship are defined as "an integral part of the whole", it couldn't get enough place in learning acquisitions. In addition, although the attention given 
to science process skills is significantly lower compared to the former curricula, results showed that they are the most dominant aim of the learning acquisitions.

\section{GİRIŞ̧}

Öğretim programları, hedeflenen öğrenme çıktılarına erişilmesi için öğretimin düzenlenmesini amaçlamaktadır. Öğretim programları birey ve toplumların gelişim ve dönüşüm ihtiyaçları doğrultusunda değişmektedir. Fen bilimleri öğretim programları geliştirme çalışmaları 2005 ve2017'de olduğu gibi gerek yeniden hazırlama gerekse 2013 ve 2018 yılında olduğu gibi güncellenme çalışmaları şeklinde yapılmaktadır. 2018 yılında yürürlüğe giren Fen Bilimleri Dersi Öğretim Programı'nda üçüncü sinıfta 36, dördüncü sinıfta 43, beşinci sinıfta 36, altınc1 sinıfta 59, yedinci sinıfta 67 ve sekizinci sinıfta 61 olmak üzere 302 kazanım bulunmaktadır. Öğretim programında mühendislik, girişimcilik, inovatif düşünme becerileri gibi konulara ağırlık verilmiş olması dolayısıyla Fen-Teknoloji-MühendislikMatematik (FeTeMM-STEM) yaklaşımının benimsendiği gözlenmektedir. Öğretim programında kazanımlara ayrılmış olan ders saatlerinin yanında dördüncü sınıftan itibaren uygulanan mühendislik ve girişimcilik uygulamaları becerilerinin geliştirilebilmesi ve yılsonu bilim şenliği düzenlenmesi amacıyla dördüncü sınıfta yıl boyu 9, beş, altı, yedi ve sekizinci sınıfların her biri için yıl boyu 12 'şer olmak üzere 57 ders saati ayrılmıştır (MEB, 2018).

Tüm bireylerin fen okuryazarı olarak yetiştirilmesi hedefinin sürdürüldüğg̈ 2018 öğretim programında dikkat çeken bir unsur da ilk defa yapılandırıcı yaklaşımın temele alındığı 2005 Fen ve Teknoloji ve 2013 Fen Bilimleri öğretim programlarının ana yapısını oluşturan öğrenme alanlarının kaldırılmış olmasıdır. 2005 öğretim programında bilimsel süreç becerileri (BSB), fen-teknoloji-toplumçevre (FTTÇ), tutum ve değerler (TD) ve fen konularını içeren fiziksel olaylar, madde ve değişim, canlılar ve hayat, dünya ve evren olmak üzere 7 öğrenme alanı (bkz. MEB, 2005); 2013 öğretim programında bilgi, beceri, duyuş, fen-teknoloji-toplum-çevre olmak üzere 4 öğrenme alanı bulunmaktadır (bkz. MEB, 2013). 2018 öğretim programında ise öğrenme alanları yerine öğretim programının yapısını özel amaçlar ve alana özgü beceriler oluşturmaktadır (bkz. MEB, 2018).

Fen bilimleri dersi öğretim programında 1739 sayılı Millî Eğitim Temel Kanunu'nun 2. maddesinde ifade edilen Türk Millî Eğitiminin Genel Amaçları ve Temel İlkeleri esas alınarak on adet özel amaç belirlenmiştir (bkz. MEB, 2018). Bu amaçlar incelendiğinde, 2005 fen ve teknoloji dersi öğretim programında bulunan yedi öğrenme alanı ve 2013 fen bilimleri dersi öğretim programında bulunan dört öğrenme alanının bütünleştirilerek özel amaçlar başlığı altında toplandığı görülmektedir: 1) Astronomi, biyoloji, fizik, kimya, yer ve çevre bilimleri ile fen ve mühendislik uygulamaları hakkında temel bilgiler kazandırmak; 2) Doğanın keşfedilmesi ve insan-çevre arasındaki ilişkinin anlaşılması sürecinde, bilimsel süreç becerileri ve bilimsel araştırma yaklaşımını benimseyip bu alanlarda karşılaşılan sorunlara çözüm üretmek; 3) Birey, çevre ve toplum arasındaki karşılıklı etkileşimi fark ettirmek, toplum, ekonomi ve doğal kaynaklara ilişkin sürdürülebilir kalkınma bilincini geliştirmek; 4) Günlük yaşam sorunlarına ilişkin sorumluluk alınmasını ve bu sorunları çözmede fen bilimlerine ilişkin bilgi, bilimsel süreç becerileri ve diğer yaşam becerilerinin kullanılmasını sağlamak; 5) Fen bilimleri ile ilgili kariyer bilinci ve girişimcilik becerilerini geliştirmek; 6) Bilim insanlarınca bilimsel bilginin nasıl oluşturulduğunu, oluşturulan bu bilginin geçtiği süreçleri ve yeni araştırmalarda nasıl kullanıldığını anlamaya yardımcı olmak; 7) Doğada ve yakın çevresinde meydana gelen olaylara ilişkin ilgi ve merak uyandırmak, tutum geliştirmek; 8) Bilimsel çalışmalarda güvenliğin önemini fark ettirerek güvenli çalışma bilinci oluşturmak; 9) Sosyobilimsel konuları kullanarak muhakeme yeteneği, bilimsel düşünme alışkanlıkları ve karar verme becerileri geliştirmek; 10) Evrensel ahlak değerleri, milli ve kültürel değerler ile bilimsel etik ilkelerinin benimsenmesini sağlamak.

2018 fen bilimleri dersi öğretim programında 2013 öğretim programında beceri öğrenme alanı altında incelenen bilimsel süreç becerileri ve yaşam becerilerine, mühendislik ve tasarım becerileri eklenmiş ve bu beceriler grubuna alana özgü beceriler adı verilmiştir (bkz. MEB, 2013; 2018).

Bilimsel süreç becerileri alt başlığında gözlem yapma, ölçme, sınıflama, verileri kaydetme, hipotez kurma, verileri kullanma ve model oluşturma, değişkenleri değiştirme ve kontrol etme, deney 
yapma becerileri; yaşam becerileri alt başlığında analitik düşünme, karar verme, yaratıcı düşünme, girişimcilik, iletişim, takım çalışması becerileri ve mühendislik ve tasarım becerileri alt başlığında ise yenilikçi (inovatif) düşünme becerisi belirlenmiştir. Mühendislik ve tasarım becerileri ile öğrencilere edindikleri bilgi ve beceriler eşliğinde bir ürün tasarlatılması amaçlanmaktadır (MEB, 2018).

Alanyazın incelendiğinde fen öğretim programlarının kazanımlarının incelendiği çeşitli çalışmalara rastlanmaktadır. Örneğin 2005 yılı fen ve teknoloji dersi öğretim programının kazanımlarının Bloom'un Aşamalı Sınıflamasına göre incelendiği bir çalışmada bilgi ve kavrama düzeyinde çok sayıda, uygulama düzeyinde az, analiz düzeyinde çok az kazanım tespit edilmiş, değerlendirme ve sentez gibi üst düzey bilişsel öğrenmeye yönelik ise hiç bir kazanım bulunamamıştır (Arsal, 2014). 2005 fen ve teknoloji dersi ögretim programının bilim okuryazarlığı ve bilimsel süreç becerileri açısından analizinin yapıldığı bir diğer çalışmada ise bilgi ve beceri öğrenme alanlarına yönelik kazanım sayılarının daha fazla, fen-teknoloji-toplum-çevre konularına yönelik kazanım sayılarının ise az olduğu belirlenmiştir. Ayrıca çalışmada bilimsel süreç becerilerinin öğretim programında önemsendiği ancak basit bilimsel süreç becerilerinin birleştirilmiş, yani daha üst düzey olan bilimsel süreç becerilerine oranla sayılarının çok daha fazla olduğu tespit edilmiş, öğrencilerin daha fazla deney tasarlayıp daha kapsamları araştırmalarla beceriler kazanmaları gerektiği vurgulanmıştır (Kılıç, Haymana ve Bozyılmaz, 2010).

\section{AMAC VE ÖNEM}

$\mathrm{Bu}$ araştırmanın amacı en son 2018 yılında güncellenen fen bilimleri dersi öğretim programında bulunan kazanımların, öğretim programında belirlenmiş olan özel amaçlar ve alana özgü beceriler açısından incelenmesidir. İncelemenin yapılabilmesi için öncelikle öğretim programındaki özel amaçlar ve alana özgü beceriler altında bulunan hedefler listelenmiş, bu hedeflere kısaca tema adı verilmiş, ardından kazanımlar incelenerek hangi kazanımın hangi temaya yönelik olduğu belirlenmiş ve bu bulgular yorumlanmıştır.

$\mathrm{Bu}$ araştırma öğretim programındaki hedeflerle kazanımların ilişkisinin kurulması ve bu ilişkinin önceki öğretim programlarla karşılaştırmalı olarak tartışılması nedeniyle fen eğitimcilere, dersin uygulayıcılarına ve dersle ilgili program geliştiricilere fayda sağlayacağı düşünülmektedir.

\section{YÖNTEM}

Araştırmada fen bilimleri dersi öğretim programı, nitel analiz yöntemlerinden içerik analizi tekniğiyle incelenmiştir. İçerik analizi, kitap, rapor, gazete, roman, haber, şark1 sözü, politik konuşmalar, reklamlar, resimler gibi genellikle yazılı bir iletişim aracının analiz edilmesidir (Fraenkel ve Wallen, 2012). Araştırmada yapılan içerik analizinden önce özel amaçlar ve alana özgü beceriler incelenerek davranışlar gruplandırılmış ve on adet özel amaç, üç adet alana özgü beceri olmak üzere toplam 13 tema belirlenmiştir.

Belirlenen temalar: 1) Bilgi; 2) Sorunlara çözüm üretmek; 3) Sürdürülebilir kalkınma bilinci; 4) Sorumluluk alma; 5) Kariyer bilinci ve girişimcilik; 6) Bilimin doğası ve bilim tarihi; 7) İlgi ve merak uyandırmak, tutum geliştirmek; 8) Güvenlik bilinci; 9) Sosyobilimsel konular; 10) Değerler ve etik; 11) Bilimsel süreç becerileri; 12) Yaşam becerileri; 13) Mühendislik becerileri şeklindedir (Tablo 1).

Temalar belirlendikten sonra 302 kazanım incelenerek bu temalara yerleştirilmiştir. Kazanımların temalara yerleştirilmesi bu araştırmanın yazarı olan iki fen eğitimcisi ve bir de program geliştirme uzmanı tarafından gerçekleştirilmiştir. Kazanımların temalara yerleştirme sürecinde, öncelikle tüm kazanımlar ve tema listesi üç uzmana da verilmiş ve üç ayrı liste oluşturulmuştur. Ardından listeler arasında bulunan farklılıklar uzmanların bir araya gelip tartışmaları ile fikir birliğine varılmıştır. Bu aşamada kazanımların bir kısmının birden fazla davranış barındırdığı tespit edilmiştir. Bu nedenle toplam 37 kazanım, bütünleşik davranış veya hedefler içerdiğinden dolayı birden fazla temaya yerleştirilmiştir. Sonuç olarak, araştırmanın veri seti 13 temaya 339 kez yerleşmiş 302 kazanım oluşturmaktadır. Bulgular ve tartışma bölümünde her tema ayrı ayrı incelenmiş ve bu temalara yerleşen kazanımlara örnekler sunulmuştur. Verilerin analizi ve yorumlanması belirlenen temaların kazanımlarla ilişkilerinin kurulması, betimsel yöntemler aracılığıyla yapılmıştır. 


\section{BULGULAR VE TARTIŞMA}

Fen bilimleri dersi öğretim programında bulunan 302 kazanımın araştırma için oluşturulan temalara $339 \mathrm{kez}$ yerleştirilmesi sonucunda kazanımların temalara dağılımı Tablo 1'de gösterilen şekildedir.

Tablo 1. Kazanımların temalara dağılımı

\begin{tabular}{lclcc}
\hline & Tema No & Temalar & $\mathbf{N}$ & $\mathbf{\%}$ \\
\hline & 1) & Bilgi & 100 & 29.49 \\
& 2) & Sorunlara çözüm üretmek & 8 & 2.35 \\
& 3) & Sürdürülebilir kalkınma bilinci & 7 & 2.06 \\
\multirow{4}{*}{ Özel Amaçlar } & 4) & Sorumluluk alma & 3 & 0.89 \\
& 5) & Kariyer bilinci ve girişimcilik & 1 & 0.29 \\
& 6) & Bilimin doğası ve bilim tarihi & 7 & 2.06 \\
& $7)$ & İlgi, merak, tutum & 6 & 1.77 \\
& 8) & Güvenlik bilinci & 5 & 1.47 \\
& 9) & Sosyobilimsel konular & 2 & 0.59 \\
\multirow{2}{*}{ Alana Özgü } & $10)$ & Değerler ve etik & 9 & 2.65 \\
Beceriler & $11)$ & Bilimsel süreç becerileri & 137 & 40.41 \\
& $12)$ & Yaşam becerileri & 43 & 12.68 \\
\hline
\end{tabular}

Kazanımların temalara dağılımları incelendiğinde en fazla kazanımın yerleştiği temanın bilimsel süreç becerileri teması (\%40.41) olduğu görülmektedir. Bilimsel süreç becerilerini sırasıyla bilgi (\%29.49); yaşam becerileri (\%12.68); mühendislik becerileri (\%3.2); değerler ve etik $(\% 2.65)$; sorunlara çözüm üretmek (\%2.35); sürdürülebilir kalkınma bilinci ile bilimin doğası ve bilim tarihi (\%2.06); ilgi, merak, tutum (\%1.77); güvenlik bilinci (\%1.47); sorumluluk alma (\%0.89); sosyobilimsel konular (\%0.59); ve son olarak kariyer bilinci ve girişimcilik (\%0.29) temaları takip etmektedir. $\mathrm{Bu}$ sonuçlar aşağıdaki başlıklar altında detaylı tartışılmıştır.

\subsection{Bilimsel Süreç Becerileri}

Bilimsel süreç becerileri ilk olarak 60'lı yıllarda Amerika'da eğitim yaklaşımı olarak kullanılmaya başlanmış ve yaklaşım günümüze kadar etkili bir şekilde kullanılmıştır (Martin, 2009). Ülkemizde de bilimsel süreç becerilerinin geliştirilmesi fen öğretiminin en önemli basamaklarından biridir (Tan ve Temiz, 2003). 2018 programı incelendiğinde alana özgü beceriler arasında bulunan üç ana başlıktan birisi olan bilimsel süreç becerilerini geliştirmeye yönelik 137 kazanım tespit edilmiştir (\%40.41). 2005 fen ve teknoloji dersi öğretim programında bilimsel süreç becerilerinin geliştirilmesi en temel ve en kapsamlı hedeftir. Bütün bilimsel süreç becerileri detaylı bir şekilde açıklanmış ve kazanımların yanında öğretilecek beceriler not olarak düşülmüştür (bkz. MEB, 2005). 2013 fen bilimleri dersi öğretim programında ise bilimsel süreç becerileri, yaşam becerileri ile birlikte beceri öğrenme alanı altında incelenmiştir (bkz. MEB, 2013). 2013 öğretim programıyla bilimsel süreç becerileri açısından benzerlik gösteren 2018 öğretim programında bilimsel süreç becerilerine verilen önemin 2005 öğretim programına göre azaldığı görülmektedir. Buna rağmen, 2018 öğretim programında bulunan kazanımların önemli bir kısmının bilimsel süreç becerilerine yönelik olduğu belirlenmiştir (bkz. MEB, 2018). Kılıç, Haymana ve Bozyılmaz (2010), 2005 fen ve teknoloji dersi öğretim programında beceriye yönelik kazanım sayısının sayıca fazla olduğunu, Arsal (2014) da aynı programda deney yapar, hesaplar, gözlem yapar, araştırma yapar gibi ifadeler içeren kazanımlara fazlaca ağırlık verildiğini belirlemiştir. 2018 öğretim programında da kapsamı çok geniş olan bilimsel süreç becerilerinin kazanımlar arasında fazlaca yer bulması olumlu bir sonuçtur. Ancak öğretim programı kitapçığında bilimsel süreç becerileri ile ilgili yeterli açıklama bulunmamaktadır. Bu temaya yönelik kazanım örnekleri aşağıdaki verilmiş̧ir:

"F.3.1.2.3. Dünya yüzeyindeki kara ve suların kapladığı alanları model üzerinde karşılaştırır.", "F.5.7.2.1. Bir elektrik devresindeki ampul parlaklığını etkileyen değişkenlerin neler olduğunu tahmin ederek tahminlerini test eder", "F.6.5.1.1. Sesin yayılabildiği ortamları tahmin eder ve tahminlerini test eder", "F.6.5.2.2. Sesin yayıldığı ortamın değişmesiyle farklı işitildiğini deneyerek keşfeder" (MEB, 2018). 


\subsection{Bilgi}

2018 öğretim programının özel amaçları arasında bulunan astronomi, biyoloji, fizik, kimya, yer ve çevre bilimleri ile fen ve mühendislik uygulamaları hakkında temel bilgi kazandırma özel amacı (MEB, 2018), 2013 öğretim programında bilgi öğrenme alanı (MEB, 2013), 2005 öğretim programında ise canlılar ve hayat, madde ve değişim, fiziksel olaylar, dünya ve evren öğrenme alanlarından oluşan temel fen kavram ve ilkeleri olarak fen eğitimcilerinin bilgisine sunulmuştur (MEB, 2005). 2018 öğretim programında bilgi kazandırmaya yönelik 100 kazanım tespit edilmiştir (\%29.49). Ülkemizde fen eğitiminde 2005 yılından itibaren yapılandırıcı öğrenme yaklaşımı, 2013 yılından itibaren araştırmasorgulamaya dayalı öğrenme yaklaşımı, 2018 yılında ise disiplinler arası bakış açısıyla araştırmasorgulamaya dayalı öğrenme yaklaşımı temel alınmıştır (MEB, 2005; 2013; 2018). Bu öğrenme yaklaşımlarında etkinlikler aracılığı ile öğrenenin bilgiyi yapılandırması, yaptığı etkinliklerle ve deneylerle keşfetmesi amaçlanmıştır. Arsal (2014) da çalışmasında 2005 fen ve teknoloji öğretim programında fark eder, tanır, listeler, belirtir gibi ifadeler içeren bilgi düzeyindeki kazanımlara çok fazla ağırlık verildiğini tespit etmiştir. Haymana ve Bozyılmaz (2010) da benzer sonuçlara ulaşmıştır. $\mathrm{Bu}$ bağlamda fen ve teknoloji öğretim programının yürürlüğe girdiği 2005 yılından bu yana bilgi düzeyinde kazanımların öğretim programlarındaki ağırlığını koruduğu anlaşılmaktadır. Bilgi düzeyinde kazanımların sayıca fazla olması fen konularının önemli bir kısmının öğretmen açısından düz anlatım ile öğretilmesi ve öğrenci açısından ezber yoluyla öğrenilmesine neden olabilir.

$\mathrm{Bu}$ tema altına yerleşen kazanımlara örnek olarak "F.4.1.1.1. Yer kabuğunun kara tabakasının kayaçlardan oluştuğunu belirtir", "F.4.1.2.1. Dünya'nın dönme ve dolanma hareketleri arasındaki farkı açıklar" kazanımları verilebilir (MEB, 2018).

\subsection{Yaşam Becerileri}

Yaşam becerilerinden karar verme, yaratıcılık, iletişim gibi beceriler 2005 öğretim programında bulunmakta, ancak adı yaşam becerileri olarak isimlendirilmemiş ve bu becerilerle doğrudan ilgili kazanım bulunmamaktaydı (bkz. MEB, 2005). 2013 yılında ilk defa alt öğrenme alanı olarak fen bilimleri öğretim programına eklenen yaşam becerilerinin, içeriği değiştirilmeden 2018 öğretim programında da kazandırılması hedeflenmiştir (bkz. MEB, 2013; 2018). 2013 ve 2018 öğretim programlarında bu beceriler bilimsel bilgiye ulaşılması ve bilimsel bilginin kullanılmasına ilişkin analitik düşünme, karar verme, yaratıcılık, girişimcilik, iletişim ve takım çalışması gibi temel yaşam becerileri olarak tanımlanmıştır (MEB, 2013; 2018). 2018 ögretim programında yaşam becerilerini geliştirmeye yönelik 43 kazanım tespit edilmiştir (\%12.68). Sandall (2003), Amerika'da yapılan fen eğitim reformlarını incelemiş ve fen eğitiminde analitik düşünme ve problem çözmeye önem verilmesi gerektiği ve fen ve matematik öğrenmede düşünme ve muhakeme süreçlerinin önemli olduğundan bahsetmiştir. Amerikan Ulusal Araştırma Konseyi (NRC, 1996) fen okuryazarlığını kişisel karar verme, ulusal meselelere katılım ve ekonomik verimlilik süreçleri için gerekli olan bilgiler, bilimsel kavramlar ve süreçler olarak tanımlanmıştır. Fen öğretim programında yaşam becerilerinin fen eğitiminde kullanılması fen okuryazarlığı hedeflerinde olumlu yönde etkileyeceği anlaşılmaktadır. Programda yaşam becerilerine yönelik önemli sayıda kazanım bulunmasına rağmen, yaşam becerileriyle ilgili yeterli açıklama yapılmamıştır.

"F.5.1.2.2. Ay'da canlıların yaşayabileceğine yönelik ürettiği fikirleri tartışır", "F. 4.2.1.3. Sağlıklı bir yaşam için besinlerin tazeliğinin ve doğallığının önemini, araştırma verilerine dayalı olarak tartışır", "F.6.6.3.1. Sistemlerin sağlığı için yapılması gerekenleri araştırma verilerine dayalı olarak tartışır" (MEB, 2018) gibi kazanımlar yaşam becerilerinin kazandırılmasına yönelik örnek kazanımlar arasindadir.

\subsection{Mühendislik ve Tasarım Becerileri}

İlk defa 2018 öğretim programında kazandırılması hedeflenen mühendislik ve tasarım becerilerini geliştirmeye yönelik 11 kazanım tespit edilmiştir (\%3.2). Alana özgü beceriler arasında bulunan mühendislik ve tasarım becerilerini geliştirmeye yönelik kazanım sayısı bilimsel süreç becerilerine ve yaşam becerilerine göre çok daha düşüktür. Ancak öğretim programının önemli hedefleri arasında bulunan bu becerilerin geliştirilmesine yönelik 4. sınıftan başlayarak 8 . sınıf sonuna kadar 57 ders saati ayrılmış ve her yılsonunda bilim şenliği düzenlenmesi hedeflenmiştir (bkz. MEB, 2018). Mühendislik ve tasarım becerilerini geliştirmeye yönelik az sayıda kazanım olmasının nedeni 
ayrılan ders saatleri ve kazanımların kapsamı olabilir. Zira tasarım ve geliştirmeye yönelik kazanımlar uzun uğraşlar ve yoğun emek harcanarak gerçeğe dönüştürülebilir. Geçmiş yıllarda mühendislik denildiğinde genel olarak bir meslekten bahsediliyormuş gibi görünse de, dünya çapında popülerleşen fen, teknoloji, mühendislik ve matematik (FeTeMM-STEM) eğitimi ile bu görüş değişmektedir. 21. yüzyılda eğitim alanındaki önemli gelişmelerden biri olarak kabul gören STEM eğitimi (Land, 2013) almış bireyler problem çözen, yenilikçi, yaratıcı, kendine güvenen, mantıklı düşünebilen, teknoloji okuryazarlı, kendi kültürünü ve tarihini eğitimiyle bağlantısını kurabilen bireylerdir (Morrison, 2006). STEM eğitimi ile uyum, iletişim, sosyal beceriler, rutin olmayan problem çözme, öz-yönetim, sistemli düşünme ve karar verme becerileri geliştirilebilir (Bybee, 2010). Mühendislik becerilerinin geliştirilmesinin birçok becerinin gelişimine katkı sağlayacağı görülmektedir. 2018 öğretim programında STEM eğitiminin önemli bir parçası olan mühendislik ve tasarım becerilerine ayrılan kazanım sayısı az olsa da, öğretim programında detaylı anlatılmış olması ve fazladan ders saati ayrılması nedenleriyle bu becerilerin geliştirilmesine önem verildiği görülmektedir. Arsal (2014) çalışmasında 2005 fen ve teknoloji dersi öğretim programında sentez düzeyinde, yani hipotez önerme, yeni, orijinal, özgün ürün tasarlama, yapma gibi ifadeler içeren kazanımlar bulunmadığını belirtmiştir. Kılıç, Haymana ve Bozyılmaz (2010) da 2005 öğretim programında basit becerilerin üst düzey becerilere göre daha fazla yer aldığını belirtmiştir. Bu bağlamda 2018 öğretim programının 2005 öğretim programına göre daha üst düzey beceriler kazandırmayı hedeflediği anlaşılmaktadır.

"F.4.5.1.2. Gelecekte kullanılabilecek aydınlatma araçlarına yönelik tasarım yapar" (MEB, 2018) kazanımı bu becerilerin kazandırılmasına yönelik örnek bir kazanım olarak gösterilebilir.

\subsection{Değerler ve Etik}

Değerler ve etik kavramları fen programı için yeni değildir. 2005 öğretim programının amaçları arasında "fen ve teknolojiyle ilgili sosyal, ekonomik ve etik değerleri, kişisel sağlık ve çevre sorunlarını fark etmelerini, bunlarla ilgili sorumluluk taşımalarını ve bilinçli kararlar vermelerini sağlamak" maddesi bulunmakla birlikte öğrencilerin olumlu tutum ve değerler içeren bir yaşam tarzı geliştirilmesinin hedeflendiği 5 hiyerarşik grupta 26 kazanım barındıran "Tutum ve Değerler (TD)" öğrenme alanı geniş kapsamlı bir şekilde ele alınmış; fen ve teknolojinin sosyal ve çevresel bağlamı başlığı altında FTTÇ etkileşimlerinin anlaşılabilmesi için fene özgü değerler yanında, topluma ve çevreye özgü değerlerin de göz önünde bulundurulması gereği vurgulanmıştır (bkz. MEB, 2005). 2013 öğretim programında ise öğretmen-öğrenci rolü başlığı altında bulunan bilgiler arasında bilimsel etik ilkelerinin öğrencilere benimsetilmesi hedeflenmiş; öğretim programının vizyonunda ise bireyin içinde bulunduğu kültüre ait değerlerin, toplumsal yapının ve inançların bilginin zihinsel süreçlerde işlenmesinde etkili olduğu belirtilmiştir. Ayrıca duyuş öğrenme alanı altında bulunan değerler alt öğrenme alanında değer, "fen bilimleri araştırmalarına ve bu araştırmaların, teknoloji-toplum-çevre ve günlük yaşam ilişkisine olan katkısına değer verme" olarak tanımlanmıştır (bkz. MEB, 2013). 2018 öğretim programının özel amaçlarında bulunan evrensel ahlak değerleri, milli ve kültürel değerler ile bilimsel etik ilkelerinin benimsenmesinin sağlanmasına yönelik 9 kazanım tespit edilmiştir (\%2.65). Öğretim programının perspektifi bölümünde değerlerimiz başlığı altında tanımlanmış olan kök değerlerin ayrı bir konu veya ünite olarak değil, eğitim sürecinin tamamına dağılmış olduğu belirtilmiştir (MEB, 2018). Ancak fen öğretim programlarında ilk kez açıklanan ve kök değerler olarak tanımlanmış olan adalet, dostluk, dürüstlük, öz denetim, sabır, saygı, sevgi, sorumluluk, vatanseverlik, yardımseverlik gibi kavramlar ile bilimsel etik ilkeleri ile ilgili az sayıda kazanım tespit edilmiştir. $\mathrm{Bu}$ kapsamda ele alınan kazanımlara verilebilecek örnekler aşağıdaki gibidir:

"F.6.6.3.2. Organ bağışının toplumsal dayanışma açısından önemini kavrar", "F.7.4.5.5. Yeniden kullanılabilecek eşyalarını, ihtiyacı olanlara iletmeye yönelik proje geliştirir" (MEB, 2018).

\subsection{Sorunlara Çözüm Üretmek}

2005 öğretim programında FTTÇ öğrenme alanında öğrencilerin edindikleri bilgi, anlayış ve becerileri sorunlara çözüm yolları ararken sorumlu ve yaratıcı çözümler geliştirmeye yönelik kullanmaları hedeflenmiş; bu hedefler iki FTTÇ kazanımıyla desteklenmiş ve öğrencilerin yaratıcı çözümler üretebilmesi için birçok becerinin birlikte kullanılabileceği "Teknolojik Tasarım Döngüsü" algoritması kullanıma sunulmuş; ayrıca Tutum ve Değerler öğrenme alanında problemlerin çözümüne duyuşsal olarak da yaklaşılmıştır (MEB, 2005). Özetle sorunlara çözüm üretmenin 2005 öğretim 
programında önemli bir yere sahip olduğu görülmektedir. 2013 öğretim programının vizyonunda ise ögrencilerin toplumsal sorunlarla ilgili problemlerin çözümü konusunda sorumlu hissetmesinin, yaratıc1 ve analitik düşünme becerileri yardımıyla bireysel veya işbirliğine dayalı alternatif çözüm önerileri üretebilmesinin önemi ve bireyin toplumsal sorunların çözümünde fen bilimleri ile ilişkili mesleklerin öneminin farkında olmasının önemi vurgulanmış; ayrıca FTTÇ öğrenme alanı altında bulunan bilimin toplumsal katkısı öğrenme alanı "bilimsel bilginin toplumsal gelişime ve toplumsal sorunların çözümüne olan katkısını anlamayı kapsamaktadır" şeklinde tanımlanmıştır (MEB, 2013). 2018 öğretim programının özel amaçlarından birisi de bu çalışmada sorunlara çözüm üretmek teması altında incelenen doğanın keşfedilmesi ve insan-çevre arasındaki ilişkinin anlaşılması sürecinde, bilimsel süreç becerileri ve bilimsel araştırma yaklaşımını benimseyip bu alanlarda karşılaşılan sorunlara çözüm üretmektir (MEB, 2018). Sorunlara çözüm üretmek temasına yönelik 8 kazanım tespit edilmiştir (\%2.35). Bu kazanımlar, öğretim programında belirlenmiş olan bazı sorunlara yönelik doğrudan çözüm üretmeye yöneliktir ve mühendislik ve tasarım becerileriyle ilgili kazanımlarda olduğu gibi gerçekleştirilmesi için vakit, emek, grup çalışması gibi unsurlara ihtiyaç duyulan kazanımlardır. Sorunlara çözüm üretmeyle ilgili kazanımlarda bilimsel süreç becerileri ve bilimsel araştırma yaklaşımı kullanılması hedeflenmiş, bir başka ifade ile kazanımlar arasında belirlenmiş bazı bilimsel, çevresel ve toplumsal sorunlara daha önceden kazanılan becerilerin kullanılarak çözümler üretilmesi hedeflenmiştir. Örneğin "F.8.4.4.7. Asit yağmurlarının önlenmesine yönelik çözüm önerileri sunar" (MEB, 2018) kazanımı birçok becerinin bir arada kullanılmasına yöneliktir.

"F.5.6.2.2. Yakın çevresindeki veya ülkemizdeki bir çevre sorununun çözümüne ilişkin öneriler sunar.", "F.4.5.5.3. Ses kirliliğini azaltmaya yönelik çözümler üretir." (MEB, 2018) kazanımları bu tema altında ele alınan kazanımlardır.

\subsection{Sürdürülebilir Kalkınma Bilinci}

Tanrıverdi (2010), 2005 yılında yayınlanan sosyal bilgiler, hayat bilgisi ve fen bilimleri öğretim programlarında sürdürülebilirlikle ilgili kazanımları incelemiş, öğretim programlarının bu açıdan yetersiz ve Avrupa Birliği ülkelerinin gerisinde olduğunu tespit etmiştir. 2005 öğretim programında kazanımlar arasında sürdürülebilirlikle ilgili davranışlar bulunsa da, öğretim programında sürdürülebilirlikle ilgili bir açıklama bulunmamaktadır (bkz. MEB, 2005). İlk olarak 2013 öğretim programında fen eğitimine dâhil olan ve "doğal kaynakların tasarruflu kullanılarak gelecek nesillerin ihtiyaçlarının karşılanmasına olanak tanınması, tasarruflu kullanımın bireysel, toplumsal ve ekonomik faydalarına ilişkin bilinç geliştirmeyi kapsamaktadır" şeklinde tanımlanan sürdürülebilir kalkınma bilinci, 2018 öğretim programında özel amaçlar arasında bulunmaktadır (bkz. MEB, 2013; 2018). Sürdürülebilir kalkınma bilinci, öğretim programında bulunan özel amaçlar arasında birey, çevre ve toplum arasındaki karşılıklı etkileşimi fark ettirmek; toplum, ekonomi ve doğal kaynaklara ilişkin sürdürülebilir kalkınma bilincini geliştirmek şeklinde açıklanmıştır (MEB, 2018). 2018 öğretim programında sürdürülebilir kalkınma bilincini geliştirmeye yönelik 7 kazanım tespit edilmiştir (\%2.06). Sürdürülebilir kalkınma bilinci ile ilgili 3. ve 5. sınıf kazanımları haricinde her sinıfta kazanım bulunmakla beraber 8 . sınıf enerji dönüşümleri ve çevre bilimi ünitesinde sürdürülebilir kalkınma adlı bir konu bulunmaktadır (bkz. MEB, 2018). Özel amaçlardan biri olmasının dışında öğretim programında tanımı yapılmamış ve öğretim programının amaçları ve perspektifi içinde bahsi geçmemesi nedenleriyle sürdürülebilir kalkınma bilincine verilen önemin 2013 öğretim programına göre azaldığı anlaşılmaktadır.

"F.8.6.3.3. Küresel iklim değişikliklerinin nedenleri ve olası sonuçlarını tartışır" (MEB, 2018) bu tema altında ele alınan kazanımlardan birisidir.

\subsection{Bilimin Doğası ve Bilim Tarihi}

Bilim tarihinin bilime karşı tutumlar (Sönmez, 2008), bilimsel kavramların gelişimi (Lederman, 2007), bilime karşı motivasyon ve cesaret, bilim insanlarına karşı toplumsal alg1 (Brush, 1989) gibi konularda olumlu etkisi bulunmaktadır. Ayrıca bilim tarihi, bilimin doğasının anlaşılabilmesi için önemli bir yol (Fouad, Masters ve Akerson, 2015; Howe, 2009; Kim ve Irving, 2010; Lederman, 1998; Şeker ve Welsh, 2006) ve bilimsel okuryazarlığının geliştirilmesi için de önemli bir yaklaşımdır (Turgut, 2007). Taşar (2003), fen bilimleri öğretim programlarında bilim tarihi ve bilimin doğası konularında daha etkili öğretim ihtiyaç duyulduğunu tespit etmiştir. Benzer çalışmalar neticesinde 2005 
ve daha sonra 2013 öğretim programlarında bilimsel okuryazarlık hedeflenmiş, bilim tarihi, bilimin doğası gibi unsurlar ön plana çıkarılmıştır. Benzer şekilde 2018 öğretim programında da bilimsel okuryazar bireylerin yetiştirilmesi hedeflenmiştir. Bilimin doğası ve bilim tarihi, 2018 fen bilimleri dersi öğretim programının özel amaçları arasında bilim insanlarınca bilimsel bilginin nasıl oluşturulduğunu, oluşturulan bu bilginin geçtiği süreçleri ve yeni araştırmalarda nasıl kullanıldığını anlamaya yardımcı olmak şeklinde tanımlanmıştır (MEB, 2018). Bilimin doğası ve bilim tarihi konularına yönelik 7 kazanım tespit edilmiştir (\%2.06). 2005 öğretim programında fen-teknolojitoplum-çevre (FTTÇ) ilişkileri altında incelenip 38 FTTÇ kazanımı arasında birçok kazanımla ilişkili olan (MEB, 2005); 2013 öğretim programında ise yine FTTÇ öğrenme alanı altında incelenen ve bilimin doğası, bilim ve teknoloji ilişkisi, bilimin toplumsal katkısı alt öğrenme alanları ayrıca açıklanmış olan (MEB, 2013) bilimin doğası ve bilim tarihi konularına verilen önemin süreç içinde sürekli azaldığ 1 görülmektedir. 2018 öğretim programında ilgili özel amaca yönelik açıklama bulunmazken, bilimin doğası veya bilim tarihi gibi kavramlar da öğretim programı içinde kullanılmamıştır.

"F.7.2.1.2. Geçmişten günümüze, hücrenin yapısı ile ilgili görüşleri teknolojik gelişmelerle ilişkilendirerek tartışır. Bilimsel bilgilerin kesin olmayıp değişebileceği ve gelişebileceği vurgulanır", "F.7.1.1.5. Teleskopun gök bilimin gelişimindeki önemine yönelik çıkarımda bulunur: $a$. Rasathane (gözlemevi) kurulma yerlerinin seçimine ve bu yerlerin taşıdlğı şartlara değinilir. b. Batılı gök bilimciler ve Türk İslam gök bilimcilerinin katkılarına değinilir" (MEB, 2018) kazanımları bu temaya yönelik örnekler olarak gösterilebilir.

\section{9. İlgi, Merak, Tutum}

2018 öğretim programının özel amaçları arasında bulunan doğada ve yakın çevresinde meydana gelen olaylara ilişkin ilgi ve merak uyandırmak, tutum geliştirmek şeklinde açıklanan (MEB, 2018) ilgi, merak, tutum temasına yönelik 6 kazanım tespit edilmiştir (\%1.77). İlgili konu, 2005 öğretim programında tutum ve değerler öğrenme alanı altında ve 5 gruptan oluşan 26 kazanım eşliğinde (bkz. MEB, 2005); 2013 öğretim programında ise duyuş öğrenme alanı altında tanımlanan tutum, motivasyon, değer ve sorumluluk alt öğrenme alanlarında incelenmektedir (bkz. MEB, 2013). 2018 programında sadece özel amaçlardan birisi içinde bulunan ilgi, merak ve tutum konularına verilen önemin, önceki programlara göre 2018 öğretim programında azaldığı görülmektedir (bkz. MEB, 2018). $\mathrm{Bu}$ temayla ilgili tespit edilen kazanımların tamamına yakını tutum geliştirmeye yöneliktir.

"F.7.4.5.4. Yakın çevresinde atık kontrolüne özen gösterir"; "F.8.6.4.1. Kaynakların kullanımında tasarruflu davranmaya özen gösterir"; "F.8.7.3.6. Evlerde elektriği tasarruflu kullanmaya özen gösterir" gibi kazanımlar tutum geliştirmeye yönelik örnek olarak; "F.7.6.2.4. Bir bitki veya hayvanın bakımını üstlenir ve gelişim sürecini rapor eder" (MEB, 2018) kazanımı ise bütünleşik bir kazanım olarak sorumluluk, ilgi ve bilimsel süreç becerilerine yönelik davranışlar geliştirmeyi hedefleyen kazanıma örnek olarak verilebilir.

\subsection{Güvenlik Bilinci}

Güvenlik bilinci 2018 öğretim programının özel amaçları arasında bilimsel çalışmalarda güvenliğin önemini fark ettirerek güvenli çalışma bilinci oluşturmak şeklinde tanımlanmıştır (MEB, 2018). 2018 öğretim programında güvenli çalışma bilinci oluşturmaya yönelik 5 kazanım tespit edilmiştir (\%1.47). Bu kazanımlardan 2'si 3. sınıf, 3'ü 8. sınıf kazanımları arasındadır. 2005 öğretim programında güvenlik bilinciyle ilgili olarak güvenlik eğitimi başlığı altında güvenlik bilgisi verilmiş, ek olarak güvenlik bilinci hem FTTÇ, hem tutum ve değerler öğrenme alanları altında kazanımlar arasında yer bulmuştur (bkz. MEB, 2005). 2013 öğretim programında güvenlikle ilgili bir hedef bulunmasa da kazanımlar arasında güvenlik bilinci geliştirmeye yönelik davranışlar bulunmaktadır (bkz. MEB, 2013).

Güvenlik bilincine verilen önemin 2005 öğretim programına göre azaldığ 1 , konunun özel amaçlar arasında ele alınması nedeniyle 2013 öğretim programına göre bir miktar arttığı görülmektedir. "F.3.4.1.3. Bireysel olarak veya gruplar halinde çalışırken gerekli güvenlik tedbirlerini almada sorumluluk üstlenir" kazanımı sorumluluk alma ve güvenlik bilincine; "F.3.7.3.1. Elektriğin güvenli kullanılmasına özen gösterir." kazanımı tutum geliştirme ve güvenlik bilincine; "F.8.4.4.6. Asit ve bazların temizlik malzemesi olarak kullanılması esnasında oluşabilecek tehlikelerle ilgili gerekli 
tedbirleri alır" kazanımı güvenlik bilincine; "F.8.7.2.2. Topraklanmayı açılar: Topraklamanın günlük yaşam ve teknolojideki uygulamaları dikkate alınarak can ve mal güvenliğin açısından önemine vurgu yapılır" kazanımı bilgi teması ve güvenlik bilincine yönelik kazanımlar olarak tespit edilmiştir (bkz. MEB, 2018). Kazanımların günlük hayatla yakın ilişkili olduğu görülmektedir. Ancak, 2018 öğretim programında doğrudan fen laboratuvarına yönelik bir açıklama, bilgi veya kazanım tespit edilememiştir.

\subsection{Sorumluluk Alma}

Sorumluluk, 2005 öğretim programında tutum ve değerler öğrenme alanı altında (MEB, 2005), 2013 öğretim programında ise duyuş öğrenme alanında incelenmiştir. 2013 öğretim programında sorumluluk, bilimsel bilgiyi geliştirmenin hem kendisi hem de toplumun diğer bireyleri için önemli olduğunu fark ederek bu konuda kendisini yükümlü hissetmesi şeklinde tanımlanmıştır (MEB, 2013). Sorumluluk alınmasına yönelik davranış geliştirmeye verilen önemin önceki öğretim programlarına göre azaldığı görülmektedir. Günlük yaşam sorunlarına ilişkin sorumluluk alınmasını ve bu sorunları çözmede fen bilimlerine ilişkin bilgi, bilimsel süreç becerileri ve diğer yaşam becerilerinin kullanılmasını sağlamak özel amacına yönelik 3 kazanım tespit edilmiştir (\%0.89).

"F.4.2.1.6. Yakın çevresinde sigara kullanımını azaltmaya yönelik sorumluluk üstlenir" (MEB, 2018) kazanımı bu temaya yönelik bir örnek olarak verilebilir. Sorumluluk almaya yönelik özel amaç, sorunlara çözüm üretmek ve bilgi temalı özel amaçlarla ve alana özgü becerilerden bilimsel süreç becerileri ve yaşam becerileriyle ortak davranışlar içermesi nedeniyle kazanımlar arasında pek fazla yer bulamamış olabilir.

\subsection{Sosyobilimsel Konular}

Sosyobilimsel konular bilimle kavramsal veya teknolojik olarak bağlantısı olan sosyal ikilemleri kapsayan ve genellikle klonlama, kök hücre, genom projeleri, küresel ısınma ve alternatif yakıtlar gibi konuları akıllara getirmektedir (Sadler, 2004). Özel amaçlar arasında bulunan ve sosyobilimsel konuları kullanarak muhakeme yeteneği, bilimsel düşünme alışkanlıkları ve karar verme becerileri geliştirmek şeklinde tanımlanan (MEB, 2018) sosyobilimsel konular teması ile ilgili 2 kazanım tespit edilmiştir $(\% 0.59)$. Bu özel amaç tamamen sosyobilimsel konular ve bu konulara bağlı tartışma becerileri geliştirmeye yönelik olduğu görülmektedir. Bu kazanımlardan bir tanesi 4. sınıf, diğeri 8. sınıf kazanımıdır. Sosyobilimsel konularla ilgili 2005 ögretim programında bir bilgi bulunmamaktadır, ancak 2013 öğretim programı amaçları arasında belirtilmiş ve FTTÇ öğrenme alanı altında bilim ve teknoloji ile ilgili sosyobilimsel problemlerin çözümüne yönelik bilimsel ve ahlaki muhakeme becerilerini kapsamaktadır şeklinde tanımlanmıştır (MEB, 2013). Sosyobilimsel konular fen okuryazarlığı hedeflerine ulaşma açısından önemli olup birçok araştırmacı tarafından öğretim sürecine etkisi incelenmekte ve sürece önemli katkıları olduğu bilinmektedir (Topçu, Muğaloğlu ve Güven, 2014).

"F.4.5.4.2. Şiddetli sese sahip teknolojik araçların olumlu ve olumsuz etkilerini araştırır" (MEB, 2018) kazanımı öncelikle bilgi ve veri toplamaya yönelik, dolayısıyla bilimsel süreç becerilerini geliştirmeye yönelik bir kazanımdır. Ancak sınıf içinde kazanıma yönelik olarak uygulanacak bir tartışma etkinliği ile olumlu ve olumsuz etkilerin tartış1labileceği bir sosyobilimsel konuya dönüştürülebilir. Bu kazanımın sosyobilimsel tartışmaya dönüştürülmesi dersin nasıl planlandığı ile ilgilidir, dolayısıyla öğretmenin tercihidir. "F.8.2.5.2. Biyoteknolojik uygulamalar kapsamında oluşturulan ikilemlerle bu uygulamaların insanlık için yararlı ve zararlı yönlerini tartışır" (MEB, 2018) kazanımı yaşam becerileri ile birlikte sosyobilimsel konu içeren tek kazanım olarak tespit edilmiştir. Özel amaç olarak belirlenmiş sosyobilimsel konulara verilen önemin 2018 öğretim programında azaldığı görülmektedir.

\subsection{Kariyer Bilinci ve Girişimcilik}

Amerikan Ulusal Fen Öğretmenleri Derneği'nin (NSTA, 2000), ulusal fen eğitimi için tavsiye olarak sunduğu ilkeler arasında "farklı kültürlerden gelen öğrencilere fen, teknoloji ve mühendislik kariyer bilinci kazandırılması fen öğretmenlerinin sorumluluğudur" maddesi bulunmaktadır. Fen bilimleri ile ilgili kariyer bilinci geliştirilmesi 2005 öğretim programı amaçları arasında bulunmakta, FTTÇ öğrenme alanında ayrıca iki kazanım ve tutum ve değerler öğrenme alanı altında bir kazanım ile geliştirilmesi hedeflenmektedir (MEB, 2005). Kariyer bilinci, 2013 öğretim programında ise yine 
öğretim programı amaçları içinde bulunmakta, girişimcilik ise yaşam becerileri arasına eklenmiş olarak görülmektedir. Ayrıca, FTTÇ öğrenme alanı altında "fen bilimleri alanındaki mesleklerin farkında olma ve bu mesleklerin bilimsel bilginin gelişimine yaptığı katkıya ilişkin bilinç geliştirmeyi kapsamaktadır" şeklinde tanımlanmıştır. Buna ek olarak, 2013 öğretim programında iki farklı ünitede kariyer bilinci kazandırılması hedeflenmiştir (MEB, 2013). Son olarak, 2018 öğretim programında fen bilimleri ile ilgili kariyer bilinci ve girişimcilik becerilerinin geliştirilmesi öğretim programının özel amaçları arasında bulunmaktadır. Bu özel amaçla ilgili sadece 8. sınıf düzeyinde 1 kazanım tespit edilmiştir (\%0.29): "F.8.4.6.2. Kimya endüstrisinde meslek dallarını araştırır ve gelecekteki yeni meslek alanları hakkında öneriler sunar" (MEB, 2018).

Kariyer bilinci ile ilgili 2018 öğretim programında özel amaçlarda bulunan bir madde dışında bir bilgi bulunamamıştır. Kariyer bilincine verilen önemin 2018 öğretim programında azaldığ görülmektedir. Ancak, girişimcilikle ilgili olarak öğrencilerin tasarladıkları ürünlerini pazarlamak için strateji oluşturmaları, ürüne yönelik tanıtım yapmaları gibi süreçleri yaşaması gibi önemli hedeflere yer verilmiştir. Girişimcilikle ilgili kazanım sayısı az olmasına rağmen, öğretim programında fen, mühendislik ve girişimcilik uygulamaları için ayrılan ders saatleri ve kapsamları girişimciliğe önem verildiğini göstermektedir.

Bulgular ve tartışma bölümünden yola çıkılarak hazırlanan Tablo 2'de temaların kazanım sayılarına göre büyükten küçüğe sıralanışı, öğretim programında ilgili temaya verilen önemin daha önceki öğretim programlara göre durumu ve önemin kazanım sayısı ile ilişkisi özetlenmiştir.

Tablo 2. Bulgular ve tartışma bölümü özeti

\begin{tabular}{clcl}
\hline Tema No & Temalar & $\mathbf{\%}$ & Açılama \\
\hline 11 & Bilimsel süreç becerileri & 40.41 & Önem düşük, kazanım sayısı fazla \\
1 & Bilgi & 29.49 & Önceki programlarla benzer \\
12 & Yaşam becerileri & 12.68 & Önem düşük, kazanım sayısı fazla \\
13 & Mühendislik becerileri & 3.2 & Önem yüksek, kazanım sayısı az \\
10 & Değerler ve etik & 2.65 & Önem yüksek, kazanım sayısı az \\
2 & Sorunlara çözüm üretmek & 2.35 & Önem düşük, kazanım sayısı az \\
3 & Sürdürülebilir kalkınma bilinci & 2.06 & Önem düşük, kazanım sayısı az \\
6 & Bilimin doğası ve bilim tarihi & 2.06 & Önem düşük, kazanım sayısı az \\
7 & Ilgi, merak, tutum & 1.77 & Önem düşük, kazanım sayısı az \\
8 & Güvenlik bilinci & 1.47 & Önem düşük, kazanım sayısı az \\
4 & Sorumluluk alma & 0.89 & Önem düşük, kazanım sayısı çok az \\
9 & Sosyobilimsel konular & 0.59 & Önem düşük, kazanım sayısı çok az \\
5 & Kariyer bilinci ve girişimcilik & 0.29 & Kazanım sayısı çok az \\
\hline
\end{tabular}

Tablo 2'de bilgi düzeyinde açıklama bulunmamaktadır. Bilgi düzeyinde fen konuları ile ilgili kazanımlar bulunduğundan ve geçmişteki ve güncel öğretim programında bu konular ve kazanımlar sayı olarak birbirine yakın olduğundan yorum yapılmamıştır. Ayrıca, kariyer bilinci ve girişimcilik özel amacı iki ayrı amacın birlikteliğinden oluşturulmuş olması nedeniyle önem değeri belirtilmemiştir. Daha önce de belirtildiği gibi yeni öğretim programında yapılan açıklamalarda daha önceki öğretim programlarına göre kariyer bilincine verilen önem azalmış, girişimciliğe verilen önem artmıştır.

\section{SONUÇ VE ÖNERILLER}

Araştırmadan elde edilen verilerin analiz sonuçları fen bilimleri dersi öğretim programında yer verilmiş olan özel amaçlar ve alana özgü beceriler ile kazanımların birbirine uyumunda bazı sorunlar olduğunu göstermektedir. Bir diğer deyişle, bazı hedeflerin kazanımlar arasında çok az yer bulduğu belirlenmiştir. Örneğin kariyer bilinci ve girişimcilik, 2018 öğretim programında "bütünün ayrılmaz bir parçası" olarak tanımlansa da kazanımlar arasında yeteri kadar yer bulamadığı; diğer taraftan bilimsel süreç becerilerine verilen önem, daha önceki öğretim programlarına göre azalmış görünse de bilimsel süreç becerilerinin fen öğretim programında önemli bir yere sahip olduğu tespit edilmiştir.

Bilindiği gibi bilgi teması altındaki kazanımlar fen konularıyla ilgili hiyerarşik bir düzende öğretilmekte, ancak diğer temalara ait bütün kazanımlar bilgi temasındaki kazanımlarla birlikte 
tekrarlanarak kazandırılmaktadır. Örneğin 5. sınıf maddenin hal değişimi konusunda bulunan "öğrenci yaptığı deney sonucunda saf maddelerin erime, donma, kaynama noktalarını belirler" kazanımında öğrencinin bilimsel süreç becerisi kullanarak ilgili fen konusunu öğrenmesi beklenmektedir. Aynı öğrenci aynı bilimsel süreç becerisini farklı konuları öğrenmek için de kullanabilir. 2005 öğretim programında bilgi öğrenme alanına (güncel öğretim programında bilgi özel amacı) ait kazanımlarla diğer öğrenme alanlarına ait kazanımlar birbirinden ayrı gruplandırılmıştır. 2013 öğretim programında ise öğrenme alanları birbirinden ayrı fakat kazanımlar birlikte verilmiştir. 2018 öğretim programında hem öğrenme alanları özel amaçlar içinde birleşik, hem de kazanımlar birlikte verilmiştir. Bu durum, öğretim programının anlaşılabilirliğini düşürmektedir. 2018 öğretim programındaki özel amaçlara bakıldığında 2013 programından bilinen Bilgi, FTTÇ ve Duyuş öğrenme alanlarının karışımı olduğu görülmektedir.

Bulgular incelendiğinde bilimsel süreç becerileri, yaşam becerileri ve mühendislik ve tasarım becerilerinden oluşan alana özgü becerilerin kazanımlar arasında yeterli sayıda yer bulduğu tespit edilmiştir. Bu becerilerin kazanımlar arasındaki toplam oranı \%56.29 seviyesindedir. Dolayısıyla bilgi düzeyindeki kazanımlar da çıkartıldığında özel amaçlarda bulunan FTTÇ ve duyuş alanlarının kazanımlar arasındaki oranı \%14.22 düzeyinde kalmaktadır. Bir diğer ifade ile doğanın keşfedilmesi ve insan-çevre arasındaki iliş̧kinin anlaşılması sürecinde karşılaşılan sorunlara çözüm üretmek; sürdürülebilir kalkınma bilinci geliştirmek; günlük yaşam sorunlarına ilişkin sorumluluk almak; kariyer bilinci ve girişimcilik becerileri geliştirmek; bilginin oluşum sürecini anlamak; doğaya ve çevresine karşı ilgi ve merak uyandırmak, tutum geliştirmek; güvenlik bilinci; sosyobilimsel konular; değerler ve etik konularının tamamının altı yıllık fen eğitimi boyunca 48 kazanımla kazandırılması hedeflenmiştir. Bu sayı, neredeyse bilimsel süreç becerilerine ayrılan kazanım sayısının üçte biri kadar, yaşam becerilerinin kazanım sayısı ile neredeyse aynıdır. Çoğu duyuşsal olan ve davranışa dönüştürülmesi uzun süren ve sık tekrarlar gerektiren bu konuların öğrencilere kazandırılması hem eğitimciler hem de öğrenciler açısından çok zorlayıcı olacaktır.

Bulgular, tartışma ve sonuç bölümünde bulunan bilgiler doğrultusunda fen eğitimi araştırmacılarına, fen bilimleri dersi öğretmenlerine ve fen bilimleri dersi program geliştirme uzmanlarına yönelik öneriler aşağıda sunulmuştur:

Fen bilimleri dersi program geliştirme uzmanlarına:

- Bu çalışmada önceki öğretim programlarındaki kazanımların sayısal değerlendirilmesi ve 2018 öğretim programı kazanımları ile sayısal karşılaştırmaları yapılmamıştır. Bu konuda bir karşılaştırma çalışması ile bazı konulara verilen önemin azalması veya artması konusunda daha net yorum yapılabilir.

- Bu çalışmada fen öğretim programında bulunan bütün özel amaçlar ve alana özgü becerilerden oluşan 13 tema doğrultusunda yorum yapılmış, ancak bu temaların her birine yönelik derinlemesine bir inceleme yapılmamıştır. Birçoğu daha önceden sıkça araştırılmış olsa da, yeni öğretim programında bulunan özel amaçlar ve alana özgü becerilerden her birine yönelik detaylı bir inceleme ve fen öğretim programlarında tarihsel bir karşılaştırma yapılabilir.

Fen bilimleri dersi öğretmenlerine:

- Öğretim programında açıklaması yapılmayan ve nasıl kullanılacağı anlatılmayan özel amaçlar ve alana özgü beceriler bulunmaktadır. Bu özel amaçların öğrencilere kazandırılması öğretmenlerin tercih ve yeteneklerine bağlıdır. Her bir kazanım ile olabildiğince fazla özel amaç ve alana özgü becerinin bağlantısının kurulması öğretmenlerin sorumluluğundadır.

Fen bilimleri dersi programı geliştiricilerine:

- Öğretim programında bulunan özel amaçların ve alana özgü becerilerin daha önceki öğretim programlarında olduğu gibi tanımları yapılmalıdır. Örneğin bilimsel süreç becerileri ve yaşam becerileri sıralanmış, bu becerilerin tanımları yapılmadığı gibi listelendikten sonra "gibi" edatı kullanılmıştır. Bu kullanım açıklayıcı olmamakla birlikte anlaşılmayı güçleştirmektedir. Bir diğer örnek ise sosyobilimsel konulardır. Öğretim programında "sosyobilimsel konu nedir?" sorusuyla ilgili herhangi bir açıklama bulunmamaktadır.

- Öğrenme alanları birleştirilerek özel amaçlar ve alana özgü beceriler olarak iki gruba ayrılmıştır. Özel amaçların mevcut haliyle sunulması, bir önceki öğretim programında bulunan bilgi, duyuş ve FTTÇ öğrenme alanlarının aynı listede olmasına neden olmuştur. Bunun sonucunda hayattaki en temel bilimsel süreç becerilerinden birisi olan sınıflandırmaya aykırı, 
karşılaştırma yapmayı engelleyen bir amaçlar grubu ortaya çıkmıştır. Amaçlar tekrar öğrenme alanları olarak gruplandırılmalıdır.

- 2018 öğretim programı da, daha önceki öğretim programları gibi sarmal yapıda olup, her yıl öğrencilere üniteler daha detaylı olarak tekrar verilmekte ve öğrenme uzun tecrübelere yayılıp kalıcı hale getirilmektedir. Ancak bu sarmal yapı, bulgular ve tartışma bölümünde tespit edilen bazı özel amaçlar için oluşturulamamıştır. Örneğin güvenlik bilincine yönelik sadece 3. ve 8. sınıflarda kazanım bulunmaktadır. Bu gibi durumlar amaçların davranışa dönüşmesinin önünde bir engel niteliğindedir. Bazı hedeflerin kazanımlar içinde daha fazla yer bulması gerektiği görülmektedir. 


\section{KAYNAKLAR}

Arsal, Z. (2014). İlköğretim fen ve teknoloji dersi öğretim programı kazanımlarının yapılandırmacılık ilkelerine göre değerlendirilmesi. International Journal of Curriculum and Instructional Studies, 2(3), 1-14.

Brush, S. G. (1989). History of science and science education. Interchange, 20(2), 60-70.

Bybee, R. W. (2010). What is STEM education?. Science, 329(5995), 996-996.

Fouad, K. E., Masters, H., \& Akerson, V. L. (2015). Using history of science to teach nature of science to elementary students. Science \& Education, 24(9-10), 1103-1140.

Fraenkel, J. R, Wallen, N.E., \& Hyun, H.H. (2012). How to Design and Evaluate Research in Education (eight edition). New York: McGraw-Hill.

Howe, E. M. (2009). Henry David Thoreau, forest succession \& the nature of science: a method for curriculum development. The American Biology Teacher, 71(7), 397-404.

Kılıç, G. B., Haymana, F., \& Bozyılmaz, B. (2010). İlköğretim fen ve teknoloji dersi öğretim programı'nın bilim okuryazarlı̆̆ı ve bilimsel süreç becerileri açısından analizi. Eğitim ve Bilim, 33(150), 52-63.

Kim, S. Y., \& Irving, K. E. (2010). History of science as an instructional context: Student learning in genetics and nature of science. Science \& Education, 19(2), 187-215.

Land, M. H. (2013). Full STEAM ahead: The benefits of integrating the arts into STEM. Procedia Computer Science, 20, 547-552.

Lederman, N. G. (1998). The state of science education: subject matter without context. The Electronic Journal of Science Education, 3(2). Online Erişim: http://unr. edu/homepage/jcannon/ejse/lederman. html.

Lederman, N. G. (2007). Nature of science: past, present, and future. In S.K: Abell \& N.G. Lederman (Eds.), Handbook of Research on Science Education, 2 (pp. 831-879). New Jersey: Lawrence Erlbaum.

Martin, D. J. (2012). Elementary science methods: A constructivist approach. Cengage Learning.

MEB [Türkiye Cumhuriyeti Milli Eğitim Bakanlığı Talim ve Terbiye Kurulu Başkanlığı], (2005). İlköğretim fen ve teknoloji dersi öğretim programı ve kılavuzu, Ankara: Devlet Kitapları Müdürlüğü.

MEB [Türkiye Cumhuriyeti Milli Eğitim Bakanlığı Talim ve Terbiye Kurulu Başkanlığı], (2013). Ilköğgretim kurumları (ilkokullar ve ortaokullar) fen bilimleri dersi $(3,4,5,6,7$, ve 8. siniflar) öğretim programı. Ankara.

MEB [Türkiye Cumhuriyeti Milli Eğitim Bakanlığ1], (2018). Fen bilimleri dersi öğretim programı (İlkokul ve Ortaokul 3, 4, 5, 6, 7, ve 8. Siniflar). Ankara.

Morrison, J. S. (2006). Attributes of STEM education: The students, the academy, the classroom. TIES STEM Education Monograph Series. Baltimore: Teaching Institute for Excellence in STEM.

NRC [National Research Council]. (2000). Inquiry and the national science education standards: A guide for teaching and learning. National Academies Press.

NSTA [National Research Council]. (2000). Inquiry and the national science education standards: A guide for teaching and learning. National Academies Press.

Sadler, T. D. (2004). Informal reasoning regarding socioscientific issues: A critical review of research. Journal of research in science teaching, 41(5), 513-536.

Sandall, B. R. (2003). Elementary science: Where are we now?. Journal of Elementary Science Education, 13-30.

Seker, H., \& Welsh, L. C. (2006). The use of history of mechanics in teaching motion and force units. Science \& Education, 15(1), 55-89.

Sönmez, V. (2008). Bilim felsefesi. Ankara: Anı yayıncılık.

Tan, M. \& Temiz, B. K. (2003). Fen öğretiminde bilimsel süreç becerilerinin yeri ve önemi. Pamukkale Üniversitesi Ĕ̆itim Fakültesi Dergisi, 13(13), 89-101.

Tanrıverdi, B. (2010). Sürdürülebilir çevre eğitimi açısından ilköğretim programlarının değerlendirilmesi. Eğitim ve Bilim, 34(151).

Taşar, M. F. (2003). Teaching history and the nature of science in science teacher education programs. Pamukkale Üniversitesi Eğitim Fakültesi Dergisi, 1(13), 30-42.

Topcu, M. S., Muğaloğlu, E. Z., \& Güven, D. (2014). Fen eğitiminde sosyobilimsel konular: Türkiye örneği. Kuram ve Uygulamada Eğitim Bilimleri, 14(6), 1-22.

Turgut, H. (2007). Scientific literacy for all. Journal of Faculty of Educational Sciences, 40(2), 233-256. 